\title{
A Case Study of Mobile Learning Pilot Project in K-12 Schools
}

\author{
Chientzu Candace Chou \\ University of St. Thomas \\ Lanise Block \\ Renee Jesness \\ Minneapolis Public Schools
}

\begin{abstract}
This case study reports findings from a four-month pilot project of one-to-one learning with iPads in four $9^{\text {th }}$ grade Geography classrooms in a large K-12 school district in the United States. The findings of the study revealed many promising opportunities and technical challenges for both teachers and students. The positive impact of iPad integration on student learning includes active engagement, increased time for projects, improved digital literacy, and digital citizenship. The challenge for student learning is mainly distraction by the multitude of irrelevant apps and Websites. With regard to instructional activities, the positive impact includes the implementation of student-centered activities and enhanced teaching practices with updated information. The challenges include a lack of teacher-selected apps and the need for more time to prep and conduct training. Faculty professional development has also played an important role on teaching practices. This study recommends continuous faculty development and student learning support through innovative approaches to transform one-to-one learning with iPads in the classroom.
\end{abstract}

Keywords: one-to-one learning, iPads, mobile learning, SAMR, performance-based professional development

\section{Introduction}

The increasing popularity of mobile devices (e.g., smart phones, tablets, E-readers) on primary and secondary school campuses has prompted a new wave of mobile learning in $\mathrm{K}-12$ education. According to a survey based on state-issued report cards and data, more than $88 \%$ of public school districts in the United States have written policies on acceptable student use of cell phones (Ed-
Tech Stats, 2010). Students in more than 2000 U.S. school districts have adopted various electronic devices in the classroom and the number is growing rapidly (Lawrence, 2012; Tate, 2012).

Taylor (2006) has defined mobile learning as "learning mediated by mobile devices, or mobility of learners (regardless of their devices), or mobility of content/resources in the sense that it can be accessed from 
anywhere" (cited in Traxler, 2009, p. 10). One-to-one learning with a mobile device falls into the same category of mobile learning in which learners use a mobile device (e.g., iPads, iPods, netbooks, laptops, cell phones, or other mobile devices) with Internet access to engage in learning activities. Many school districts may restrict the access to classroom use (Koebler, 2011) for fear of damage, lost, or misuse. Therefore, some one-to-one learning initiatives do not go beyond the boundaries of the school buildings. Nevertheless, one-to-one learning with mobile devices provides greater flexibility for learners to access learning content on their own pace regardless of the location. Mobile devices in the classroom have solved some immediate challenges in schools such as overbooked and inaccessible computer labs. In addition, enhanced features such as multimedia, communication, and collaboration tools have provided new learning opportunities that transcend the confines of formal learning in the classroom. Of all recent mobile devices in the U.S. educational market, iPads stand out for their ease of use and multiple functions powered by an increasing number of apps.

An increasing number of American K-12 schools are adopting various mobile devices to replace textbooks and laptops (Gliksman, 2011; Roscoria, 2011). The use of mobile devices for learning in the K-12 classroom is changing the educational landscape (Roscoria, 2011), but the impact on student achievement is unclear. There is a paucity of research on the impact of mobile devices such as iPads in K-12 education. How is the use of iPads enhancing or hindering student learning? How is the use of iPads contributing to or inhibiting teacher instruction? What learning opportunities can iPads afford students and educators that are different from other mobile devices? How can professional development empower teachers in technology integration? The goal of this research aims at exploring the impact of iPad integration on learning activities and teacher/ student perceptions of one-to-one learning with iPads in the classroom. This study was set up to answer this main research question: What are the challenges and opportunities in one-to-one learning with iPads for teachers and students in the K-12 classrooms? The findings of the study can provide insights and best practices of oneto-one learning in K-12 education.

\section{Literature Review}

\subsection{Educational Potentials}

Studies have shown that integrating iPads with sound curriculum can contribute to increased student engagement, collaboration, productivity, technology competency, innovation, and critical thinking (Gertner, 2011; McConnell \& McConnell, 2011; Morelock, 2011; Shepherd \& Reeves, 2011). Recent studies on iPads were mostly based on data taken from college students. After teaching a college class with iPads and another class with laptops for one semester, Shepherd and Reeves (2011) compared the course management system Blackboard's access logs between the two classes. They found students from the class that used laptops accessed the Blackboard site mostly during class time. Students from the iPad class have had a more diffused pattern of accessing the Blackboard site. In other words, iPad users continued to access the class Blackboard site throughout the day even outside class sessions. They concluded that the mobile device has made it easier to access class materials. They have also found new level of student engagement in course participation because "with the use of Mobile devices within the classroom, students have new levels of responsibility to actively participate in real-time polls, discussions, blogs, and other course activity" (p. 14). In a larger implementation of iPad in which every incoming college freshman received an iPad, Wagoner, Hoover, and Ernst 
(2011) summarized their findings into six categories: digital divide, media production, personal productivity, information literacy, sustainable classroom, and learning beyond the classroom. Instructors were optimistic that iPads could reduce the digital divide in the classroom when everyone has access to an iPad. Instructors were more willing to require students to complete activities using iPads. Instructors were utilizing more media production for assignments such as photo journals, e-documents, speeches with images projection, short movies, etc. Instructors were very positive about the ease of use of iPads. Many have utilized iPads to send emails or schedule appointments with students. Students were utilizing iPads to conduct research for class assignments or collect data for research. All these activities increased their information literacy. The classrooms became more sustainable due to a reduction in printing cost. Students and teachers were utilizing iPads for presentations and correspondence to avoid unnecessary printing. Many teachers changed curriculum to encourage learning beyond the classroom such as using iPads to collect research data or conduct interviews in the local community.

The mobile device alone will not encourage student engagement or productivity. Educators need to be able to integrate mobile devices and apps into the curriculum to reap the benefits. In a study by Pepperdine University, the researchers have outlined some of the challenges and benefits in three areas: support, compatibility, and integration (Pepperdine University, 2012). For supporting student use of iPad apps, faculty encouragement was not sufficient. Peer pressure, student collaboration, or faculty assignment requirements were the best way to ensure students' utilization of apps to get job done. Although there was a learning curve for both students and faculty, if faculty demonstrated proficient knowledge in apps for specific assignments (e.g., note-taking, email, e-reader) students could better ease into oneto-one learning with iPads. Choosing apps that were compatible with a faculty's teacher style and creating iPad-friendly course materials were both very important as well. If a class assignment cannot be retrieved on iPads due to limitation on Flash videos or Java, it would add unnecessary student frustration. Finally, using apps that were highly relevant and purposefully integrated into the curriculum was vital to student learning. Otherwise, iPads to students would be just entertainment and reading devices.

In a K-12 school district report, Morelock (2011) observed a higher percentage of students achieving Math and Reading proficiency at the appropriate grade levels after the teachers started integrating iPod Touch into the classroom for one year. Student test scores also evidently improved based on teachers' data. Students with disabilities, economically disadvantaged students, and ELL students in the classrooms with mobile devices all performed better than students of the same categories in the whole district. Can this kind of success be duplicated to other educational institutes? More research in this area is definitely needed. With sound pedagogy and implementation, one-to-one learning has the potential to transform the classroom into a true learner-centered learning environment in which communication, collaboration, and creative problem solving flourish to create student-driven learning. In a report of more than 25 handheld learning projects, Shuler (2009) found that the key opportunities for mobile learning include:

1. Encourage "anywhere, anytime" learning: Students can gather and process information outside the classroom to learn in a real-world context. 
2. Reach underserved children: The low cost of a mobile device makes it accessible to low-income families and can help advance digital equity.

3. Improve $21^{\text {st }}$-century social interactions: Mobile technologies can promote and foster communication and collaboration; all important skills of the $21^{\text {st }}$ century.

4. Fit with learning environments: Mobile devices can fit easily into many learning environments and eliminate the barriers associated with large devices.

5. Enable a personalized learning experience: Mobile devices allow differentiated instruction for diverse learners who can learn at their own pace.

Shuler (2009) remarked that mobile devices might be used to capitalize on the personalization capabilities of the devices that make learning more accessible. Mobile devices have bridged learning in school, afterschool, and home environments.

\subsection{Educational Challenges}

Recent reports from K-12 schools on iPad integration have pointed out a few challenges, including app selections, tech support, device management (Alberta Education, 2011), and professional development (Hatten, 2012). Harmon (2012) pointed out that the app selection is a process of trial and error. Facing the ever-changing field of app development, novice teachers would find it a daunting task to select appropriate apps to integrate into the curriculum. Many educators also do not have the budget to purchase paid apps. Harmon (2012) suggests that eliciting student help might be one of the best ways to incorporate iPads in the classroom because students are the best judges of what tools engage them. In addition, some apps let students choose the difficulty levels and move through the levels at their own pace. The ability to adjust content to student level and allow self-paced learning lends iPad as an ideal tool for implementing differentiated instruction. Furthermore, the use of iPads can allow students to make decisions regarding of their learning pace and presentation preferences. To select appropriate apps, educators could invest time following Websites that update educational apps in various disciplines to stay current. Moreover, incremental integration of iPad apps would "acclimatize" educators to the one-to-one learning environment in their own pace as well.

According to the Alberta Ministry of Education (2012) in Canada, the challenges of tech support and device management were evident in the rollout of iPad classroom sets. A teacher may use the same iPad cart for multiple classrooms. Content sharing on devices that was designed for personalization became a potential issue. Before effective managing apps or software programs can be introduced to manage iPads, teachers are playing a more active role on iPad management. In some cases, teachers have to rely more on tech support or instructional support to integrate iPads because they have potentially presented new technical challenges for teachers (Alberta Education, 2012). It could be cumbersome and time consuming for teachers to have to manage the devices and rely on tech support to get the job done in a classroom with an iPad cart. Conn (2012) recommends that involving students in setting up the ground rules and policies of iPad usage could create a sense of ownership for students and eliminate ambiguity in content sharing. Advocating good digital citizenship is essential to ensure content privacy and ethical behaviors.

Another area of challenge is professional development. Hatten (2012) emphasized the importance in providing multiple forms of support for teachers. Professional development 
could be in the form of workshops, mentoring, coaching, job-embedded professional development, online and faceto-face communities, and just-in-time videos (Alberta Education, 2012; Hatten, 2012). The following section will discuss two models of professional development.

\subsection{Professional Development Models}

With one-to-one learning, students have the opportunity to benefit from a transformed classroom in which they are actively engaging in learning activities that address the $21^{\text {st }}$ century learning skills (Partnership for 21st Century Skills, 2011). The mobile devices alone do not transform the classroom. Technology is a tool to deliver instruction or serve as a medium for collaboration. Instructional design of activities is the key. Enhanced teaching practice and sound pedagogy need to be embedded in the professional development opportunities for teachers. Professional development should focus on both the content and performance improvement. Content refers to the pedagogical and technological contents that enable educators to advance student learning. Performance improvement refers to enhancing the educators' capability to do the job well. For the content part of the professional development, Puentedura's (2009) SAMR model aims at transforming learning with technology. SAMR stands for substitution, augmentation, modification, and redefinition. At the basic levels, technology can be used to substitute print text and augment traditional face-to-face learning. At higher levels, the use of technology should aim at transforming the learning experiences through modification and redefinition. Learners can work with peers or experts in the field to engage in authentic learning as shown in figure 1.

Specifically, with one-to-one learning students can now be historians in creating

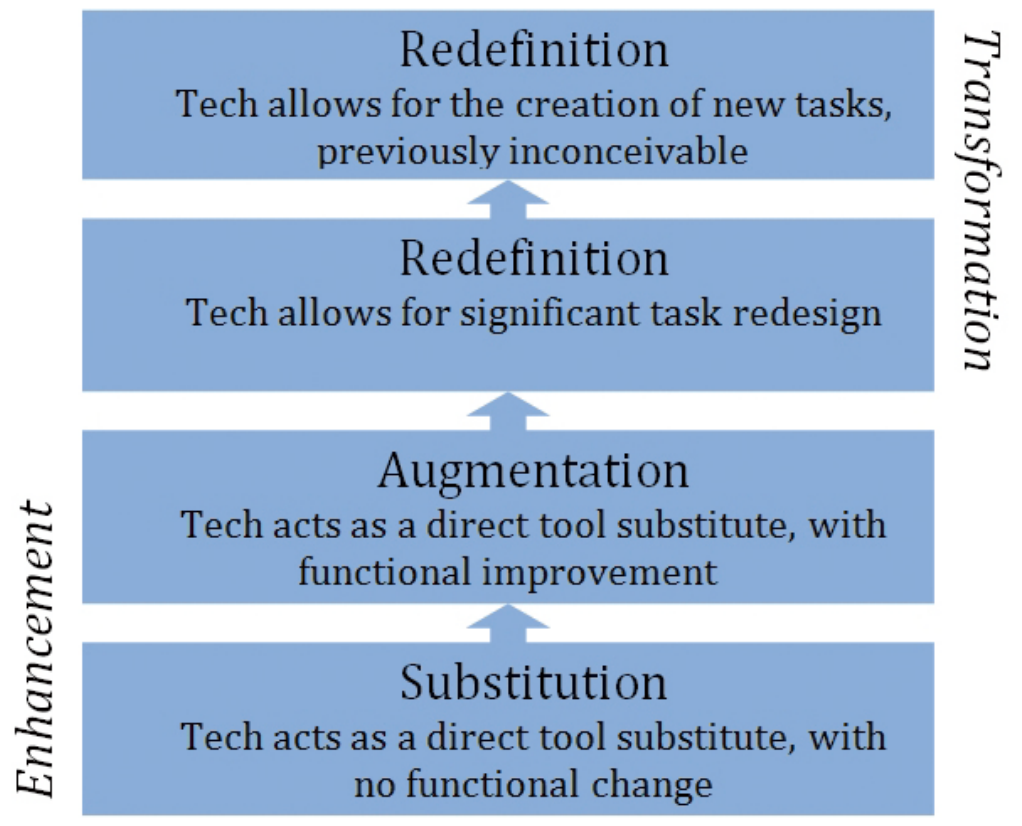

Figure 1. SAMR (revised from Puentedura, 2009) 
digital stories about a historical event, explore manipulative learning environments to further their understanding of math, use simulations to understand an abstract science topic, and maintain a personalized learning network to sustain life-long learning. Although all these tasks can be accomplished through desktop computers or laptops, access to the computer lab on a sign-up basis is much more limiting in granting access to digital resources and the Internet than the every day access of a oneto-one learning environment in the classroom with iPads.

In addition to the emphasis on the pedagogical and technological contents, faculty performance is also an essential part of professional development. Technology integration is more than just using the tools. It requires careful instructional design that links learning objectives to specific learning tasks or activities that lead to measurable outcomes. Not all faculty members have the technology expertise to create technologyenriched learning experiences. In assisting faculty adopting new technology, one should also consider the effectiveness of the adaptation (i.e., how well can faculty integrate iPads in the classroom). The process involves multiple stakeholders and faculty cannot do it alone. Faculty development should be a systemic process to ensure effectiveness of iPad integration. Fang (2007) proposed a Performance-Based Faculty Development Model to address the key factors in institutional implementation of faculty development. The Model consists of five main components: formal training, communities of practice, performance support, formative evaluation, and knowledge sharing. The model is a shift from emphasizing faculty training to performance improvement, which involves training, motivation, and support (Fang, 2007). Formal training such as workshops provides the opportunities to assist faculty members who are lacking the basic skills needed for iPad integration. Communities of practice encourage peer-learning and learnercentered approach to learning new skills from experienced faculty members. Performance support can be implemented through online resources, in-house staff, just-in-time online assistance, or online tutorials. Formative evaluation aims at improving the process while the program is in progress to provide timely help to faculty members. Knowledge sharing encourages a participation culture of connection, sharing, and open-endedness through networking or in-person dialogues.

This section examines the opportunities and challenges in recent studies or reports of iPad integration in educational institutions. Although there were great promises, there were also many issues surrounding one-toone learning implementation. Tech support and device management are recurring themes in each phase of emerging technology integration. App selection is unique to iPads and can be addressed through continuous professional development as highlighted in Fang's model. Mobile devices such as iPads will enable learning at a higher level with greater accessibility to online digital resources and the Internet. As Shuler (2009) stated, "Mobile technologies bring the real world into the classroom and they bring the classroom into the real world" (p, 17). We are working with a generation of mobile learners and need to connect with them via the tools that they are familiar with to maximize their learning interests.

\section{Background}

\subsection{Project Scope}

The school district in this case study is a large public school in a Midwest city in the United States. The school district has more than 32,000 students with $68 \%$ students 
of color. Sixty-six percent of the student population in the district received free or reduced lunch in the 2011-12 school year. Four 9th grade Geography classrooms were chosen as part of an iPad pilot project in spring 2012 before additional rollout of iPad carts to all $9^{\text {th }}$ grade Geography classrooms in fall 2012. The four teachers and students in the four classrooms are the subjects for this study. Each classroom received an iPad cart with 30 iPads for classroom use only. In addition to the four classroom teachers, four Social Studies teachers were recruited to explore the pedagogical applications of iPads in the classrooms. All eight teachers participated in the monthly professional training meetings to share ideas about iPad integration.

\subsection{Faculty Development}

Both Puentendura's SAMR (2009) and Fang's (2007) performance-based faculty development model were adopted into the professional development. The SAMR model was embedded in the instructional examples in the monthly meeting and Websites. To address the five components in Fang's (2007) performance-based faculty development model (formal training, community of practice, performance support, knowledge sharing and evaluation), the following professional development opportunities were introduced. Formal training was provided through monthly meetings during regular semesters. A community of practice was established through SharePoint (a content management system) to provide faculty information on best practices with one-to-one learning. Faculty could also share their experiences in their own classroom through SharePoint. The performance support was provided by the Teaching and Learning and the IT departments at the school district. Knowledge related to one-to-one learning (e.g., tips for using apps and trouble-shooting ideas) were shared through SharePoint and monthly meetings. Evaluation was conducted through four classroom observations, one teacher focus group, and four student focus groups.

\section{Research Method}

This is an exploratory case study that examines how the implementation of one-toone learning with iPads can contribute to or inhibit teaching and learning activities in the classroom. The use of a case study method is appropriate because it provides in-depth examination of the iPad implementation for one-to-one learning in K-12 classrooms. This approach can provide a holistic account of the phenomenon under investigation (Yin, 2003). This pilot study examined four $9^{\text {th }}$ grade Geography classrooms in a large district located in a major city in the Midwest U.S. The participants include four high school teachers ( 2 females and 2 males) and their students. Thirty-one students (14 females and 17 males) participated in the student focus groups. The researchers have also observed four classes with a total of approximately 120 students.

\section{1. Research Questions}

This project will address the following research questions:

What are the factors that contribute to student learning and teachers' facilitation of learning with mobile devices? Specifically, the researchers are interested in exploring the perceived and observable opportunities of iPad integration that enhance student engagement and performance.

What are the factors that inhibit student learning and teachers' facilitation of learning with mobile devices? The researchers are looking for lessons learned from iPad integration and participant experiences that are unique in this pilot project. 
What are the impact of professional development on teachers? What instructional activities have instructors utilized based on the SAMR model? How can the performance-based faculty development model be further improved?

By addressing the research questions, we could make recommendations on ways to improve one-to-one learning in the classroom.

\subsection{Data Collection}

Yin (2003) emphasized three principles in the data collection procedure in conducting a case study: (1) multiple sources of evidence, (2) a case study database, and (3) a chain of evidence (explicit links between the questions asked). Following these three principles, we have collected data from three data sources, established a database of the evidence, and used consistent questions for all data collected. The three data sources are:

Teacher focus group: Teachers were invited to a focus group toward the end of the iPad pilot project. The teacher focus group was conducted during the last professional development meeting at the fourth month of the pilot project. Three out of the four classroom teachers participated in the focus group. One had a time conflict and was invited to contribute to the focus group questions in writing. The questions focused on the following areas: (a) factors that contribute to student learning and teacher instruction with mobile device, (b) factors that inhibit student learning and teacher's facilitation of learning, (c) impact of iPads on teaching, and (d) improvement for professional development. The detailed questions can be found in Appendix 1. The meeting minutes were sent back to teachers for review to verify accuracy.

Student focus group: A student focus group was conducted at each site for a total of four student focus groups. The numbers at each school ranged from 3 to 14 students. A total of 31 students participated in the focus groups. The student focus group questions (see Appendix 2) concentrated on the following areas: (a) the pros and cons of iPads in the classroom, (b) impact of iPads on student learning, and (c) understanding of the subject matters.

Classroom observation: A classroom observation form (see Appendix 3) was modified from the Pepperdine University' s research project (2012) to describe the classroom activities including types of instructional activities, teacher-student interaction, and student-student interaction. Each classroom was observed once toward the end of the pilot project; roughly three months after iPad carts were installed in the classrooms. Three observers who were also the researchers observed all four classrooms together and took notes. A total of approximately 120 students were observed in the four classes.

The three researchers conducted the focus groups, observed the classes together, and took copious notes on the responses made from teachers and students. After the observations and focus group discussions, the researchers compared notes and discussed at length on the observable themes from the data. The emerged themes from the data are based on observable instructional events and highlights made from the focus groups that all three researchers have agreed upon. The first researcher is a university faculty of learning technology. The second researcher is the lead teacher of Social Studies and a veteran teacher of 15 years. The third researcher is the district technology integration strategist and a veteran educator of $30+$ years. None of the researchers have direct supervision responsibilities over the teachers in the pilot project. 


\subsection{Data Analysis and Results}

The researchers compared notes and discussed at length of their findings during the focus groups and classroom observations. The preliminary data have yielded much interesting information on the impact of iPads on instructional activities and teacher/student perceptions toward iPads. The reactions to iPads have been predominately positive with some reservations. The advantages and challenges are outlined in the sections below. The sources of the evidence that were quoted in the tables were from teacher focus group, student focus groups, or classroom observations.

4.3.1. Educational opportunities. To address the first research question on the factors that contribute to student learning and teacher instruction with iPads, the following themes have emerged from the data as summarized in table 1:

Table 1. Opportunities of One-to-One Learning for Students and Teachers

\begin{tabular}{|c|c|}
\hline Student Benefits & Evidence: Focus groups quotes and classroom observation notes \\
\hline $\begin{array}{l}\text { 1. Active engagement: } \\
\text { There are more varieties } \\
\text { of apps than on the } \\
\text { computers for student- } \\
\text { centered activities. }\end{array}$ & $\begin{array}{l}\text { - Teacher focus group: "iPads do engage students. They were } \\
\text { busy the whole time." "Some days, I have kids } 100 \% \text { on task, all } \\
\text { day." "Students played games to prepare for final tests. Their test } \\
\text { scores have improved significantly." } \\
\text { - Student focus group: "It increases my ability to communicate and } \\
\text { engage in discussions." "There are lots of resources that I can } \\
\text { use. I was challenged by iPad to learn more." } \\
\text { - Classroom observation: Students got on tasks right away with } \\
\text { occasional questions for teachers. In one class, students sat in } \\
\text { circles and engaged in discussions while searching on the Web } \\
\text { for information. }\end{array}$ \\
\hline
\end{tabular}

2. Increased time for projects: Students could start a project or task as soon as they enter the classroom without wasting time starting up the equipment.
- Teacher focus group: "Today I met the kids at the door, they signed in and took the iPads. By the time the bell rang, they had the iPads and were ready to go; whereas in the media center, you have to close five minutes earlier. It did save time."

- Student focus groups: "We can do more assignments. In the past, we can do only one project in the computer lab. For example, the environment project, we could spend two days researching and type right away."

- Classroom observation: Students engaged in information search, small group discussion, and complete a worksheet at the same time. Students could work independently or in teams. 


\section{Improved} information literacy and digital citizenship:

Students could conduct information search at a faster pace. They also learned about digital citizenship through the process.
- Teacher focus group: "TodaysMeet has the transcripts of online conversations. If students have said something indecent, the teachers would have evidence to make a referral to transfer students out." "My students are tech savvy now. " I found significantly reduced rate of plagiarism in student writings."

- Student focus groups: "You can do a speech with images and you can put them all together on iPads. Your projects can have more varieties: images, songs, and videos. It's really cool. " "we don't have to wait for each other for information, we can find info on our own, we can find different information, it's faster and very helpful."

- Classroom observation: Students used a variety of apps and websites to communicate ideas. They also corrected each other when errors were made.
Teacher Benefits

1. Student-centered activities: Students could learn at their own pace, collaborate with a team, and offer advice to each other through various apps.

\section{Evidence}

- Teacher focus group: "I do a lot of chats and online discussions. Kids who never speak would speak up. I have better relationship with students." "Student taught each other apps such as Idea Sketch."

- Student focus group: "There are more sharing. We learn from each other and get new ideas from each other." "Increaes my ability to communicate and to engage in discussions." "It has increased our collaboration. We look for information and form groups to solve problems together."

- Classroom observation: Teachers spent less time giving instructions and more time in assisting individual students in completing projects. Most activities were accomplished through self-paced learning within a reasonable timeframe.

2. Enhanced teaching with updated information: Teachers could use apps with up-to-date Geography information to engage students.
- Teacher focus group: "Give the classroom more resources. It's nice and it has made me rethink the type of lessons I have to teach. It gives me up-today information to teach." "A teacher needs to be very prepared before each session." "It's nice to have something new. It's better when I am learning something."

- Student focus groups: "It gives you more information about a research project. It tells you more updated news than the textbook."

- Classroom observation: Teacher used TV News to engage students in conversation that showed equal student participation. 
Table 2. Challenges of One-to-One Learning for Students and Teachers

\begin{tabular}{|c|c|}
\hline Student Challenges & Evidence: Focus groups quotes and classroom observation notes \\
\hline $\begin{array}{l}\text { 1. Distraction: Students } \\
\text { could get off track while } \\
\text { looking up information } \\
\text { on the Website or } \\
\text { attempt to use apps that } \\
\text { were more entertaining } \\
\text { and not central to the } \\
\text { task. }\end{array}$ & $\begin{array}{l}\text { - Teacher focus group: "Kids got off easily. If you don't walk } \\
\text { around, they would skip to take pictures, use it as mirror, and } \\
\text { surf the Web and sport sites." } \\
\text { - Student focus group: "Some kids got distracted, not using it } \\
\text { appropriately. Sometimes students may take advantages and use } \\
\text { it for the wrong reasons. They have photo booth so they may take } \\
\text { pictures, not doing their work." } \\
\text { - Classroom observation: Some students took a long time } \\
\text { browsing on the Web and did not complete the required task. }\end{array}$ \\
\hline
\end{tabular}

\begin{tabular}{l}
\hline Teacher Challenges \\
\hline 1. Lack of teacher- \\
selected apps: Although \\
there are a number of \\
Geography apps, there \\
could be more apps \\
for word processing, \\
Geography-related \\
topics, and challenged- \\
based activities.
\end{tabular}

Evidence

- Teacher focus group: "What will be improved is that the lessons are already created for teachers. It will be more helpful to have more geography apps."

- Student focus groups: "Put more educational apps and educational games. If we were given more choice, there will be more fun. We were told to do certain things but not given many choices."

- Classroom observation: Students spent the whole class on one app to work on one task. Students who finished their tasks earlier did not have other assignment and started chatting.

\section{Need more time and} training: iPad as a new mobile device poses challenges for both teachers and students who have not used mobile devices.

- Teacher focus group: "A handful of kids have never used mobile devices or cell phones. It's more difficult to get them started." "Time to prep, to teach ourselves about the apps, and time to use them in the classroom." "To know what we should be using. Emphasize the five six apps for the first two weeks that teachers and students should know"

- Student focus groups: "Give us orientation on the use of iPad, basic common sense training such as closing browser tabs."

- Classroom observation: Some students would continue to ask technical questions after teacher demonstration.

The educational benefits have corroborated with the literature in many ways. Mobile devices such as iPads increase student engagement; teachers have commented that the students were $100 \%$ on tasks and engaging in classroom discussions. Students have more time to engage in projects and/or access school projects from home to continue the practice. Student-centered activities can be easily created to encourage student collaboration (Shuler, 2009). Students were more aware of digital citizenship and data privacy as iPad use 
became a daily practice. Teacher's comment on the significantly reduced rate of student plagiarism highlights a creative solution of iPad integration in which students had to take notes while searching for resources for a research project. They later had to draft a research paper based on their personal notes that eliminated direct copy-and-paste from the Internet. Finally, students now have more time to work on projects because iPads have become more accessible than the computer labs. Current events and updated Geographical information can also be retrieved at a much faster pace than from print materials such as books and the atlas.

4.3.2. Challenges. To address the second research question on the factors that inhibit instructional activities, the following themes are found in the data as summarized in Table 2.

The challenges faced by the teachers and students are typical in most technology integration, including student distraction and time for prep. The lack of appropriate apps is unique to iPads because there are many proprietary programs that are controlled by Apple. There are also many third party apps for exploration. Teachers might not have sufficient time to juggle the tasks of tech troubleshoot, app selections, and device management in a short time period. These issues were also echoed by the other school districts (Alberta Education, 2012), and the district needed to provide instructional and tech support to enable teachers to do their jobs well.

\subsubsection{Professional development: Based on} the teacher focus group and monthly meeting discussions, teachers have emphasized strongly that the monthly professional development workshops have played an important role in boosting their confidence and providing innovative ideas for iPad integration. Many teachers were skeptical of the benefits of
iPads and would rather have a cart of netbooks or laptops for instructional activities at the beginning of the iPad pilot project. There were many limitations on the app purchase and installation. The teachers were the first group in their own schools to use iPad so that they had to be resourceful in finding tech support or did the minimal to keep the iPads functional. At the end of the first month, all teachers have come up with their routines for student iPad check-out. Through monthly idea sharing, they have also gradually developed unique ways to integrate iPads for learning Geography in the classrooms. In terms of the SAMR model, the types of activities included substitution of Atlas with online map app, augmentation of classroom discussion with online chat, modification of research project with a concept map and updated information from credible online databases, and redefinition of collaboration through clear division of labor on personalized iPads and quicker communication channels. All teachers have expressed strong interest in continuing iPad carts in their classrooms and would find it difficult to teach without iPads in the new academic year.

Based on the collected data, the preliminary findings of the study have revealed many promising opportunities and technical challenges for both teachers and students. The positive impact of iPads integration on student learning includes active engagement, increased time for project, and improved digital literacy and digital citizenship. The challenge for student learning is mainly distraction by the multitude of irrelevant apps and Websites. It requires strong self-discipline and constant teacher supervision for students to stay on track. With regard to instructional activities, the positive impact includes the implementation of student-centered activities and enhanced teaching practices with updated information. The challenges include a lack of teacher-selected apps and the need for more 
time to prep and train. The currently available free apps such as ArcGIS and Google Earth all have their limitations. Utilizing apps that match with the curriculum to encourage student collaboration and creativity would create a true student-centered classroom.

\section{Conclusion and Recommendations}

As Shuler (2009) puts it, one-to-one learning with a mobile device will "enable kids to develop passions and interests via their own personalized, media-enhanced environments that can transport them to different times and places" (p. 22). We have witnessed first hand, how engrossed the students were with their iPads. Although we have observed that most of the instructional activities stayed at the basic two levels of substitution and augmentation according to Puentedura's SAMR model (2009), given time and more collaboration among teachers, we are confident that we will see more instructional activities that maximize the full potentials of iPads. The following recommendations will help lay the groundwork for solid one-to-one learning:

1. Modeling transformative teaching practice during the faculty professional development workshops: Provide more examples of best practices and encourage teachers to incorporate activities that are modification or redefinition of the existing practices. Establishing a social network for teachers to share ideas and information throughout the school year can provide continuous performance support.

2. Providing training opportunities and resources for students at the early stage: Although we are working with digital natives, students would want to know why they use iPads in the classroom, how to use them properly, and when to use Pads for what purposes. Digital citizenship should be emphasized to remind students of appropriate online behaviors. Training materials can be made available in person or via the Web to deal with schools with high student turnover rate. Alternatively, identifying student tech ambassadors who are more tech savvy at each school will provide timely support for instructors during instruction.

One-to-one learning with iPads is still in its infancy. Further study on how to truly engage students in using iPads to communicate, create, and collaborate will provide meaningful instructional practices for educators. Future research could also include quantitative data such as student performance (e.g., grades), student improvement of $21^{\text {st }}$ century digital and media skills, teacher use of apps and the frequency, and participant tech skills to provide comprehensive data for analysis. With increasing market shares of other tablets such as Android, research can also include other similar mobile devices to provide a holistic picture of one-to-one learning landscape.

\section{References}

Alberta Education. (2012). iPads: What are we learning? Summary report of provincial data gathering day. Retrived from http:// education.alberta.ca/admin/technology/ research.aspx

Conn, C. (2012). Managing and maximizing a class set of iPads. Learning and Leading with Technology, 39(8), 32-33.

Ed-Tech Stats. (2010). Education Week, 29(26), 36-37.

Fang, B. (2007). A performance-based development model for online faculty. Performance Improvement, 46(5), 17-24.

Gertner, R. T. (2011). The Effects of Multimedia Technology on Learning. MS, Abilene Christian University. Retrieved from http://www.acu.edu/technology/ 
mobilelearning/documents/research/ effects-of-technology-on-learning.pdf

Gliksman, S. (2011). What do Students Think of Using iPads in Class? Pilot Survey Results. Retrieved from http:// ipadeducators.ning.com/profiles/blogs/ what-do-students-think-of

Harmon, J. (2012). Unlock literacy with iPads. Learning and Leading with Technology, 39(8), 30-31.

Hatten, S. H. (2012). iPod implementation in the elementary grades. Learning and Leading with Technology, 39(7), 30-31.

Koebler, J. (September 7, 2011). More high schools implement iPad programs, U.S. News. Retrieved from http://www. usnews.com/education/blogs/high-schoolnotes/2011/09/07/more-high-schoolsimplement-ipad-programs

Lawrence, S. D. (April 4th, 2012). iPad use in schools on the rise. Education News. Retrieved from http://www. educationnews.org/technology/ipad-usein-schools-on-the-rise/

McConnell, B., \& McConnell, S. (2011, June 26-29). Mobile Devices in a ProjectBased Physics Classroom: Developing NETS-S in Students. Paper presented at the International Society for Technology in Education (ISTE) conference, Pennsylvania, PA.

Morelock, J. (2011). Mobile devices in Canby SD: Meeting the needs of every student. Retrieved from http://wiki. canby.k12.or.us/groups/ipodusergroup/ weblog/6a110/attachments/daa48/ ipodachievementdata-20092010.pdf

Partnership for 21st Century Skills. (2011). Framework for 21 st Century Learning, Retrieved from http://www.p21.org/ overview

Pepperdine University. (2012). iPad research study. Retrived from http://community. pepperdine.edu/it/tools/ipad/research/

Puentedura, R. (2009). Transformation, technology, and education, Retrieved from http://hippasus.com/resources/tte/

Roscoria, T. (2011). The Impact of the iPad on K-12 Schools. Retrieved from http://www. convergemag.com/classtech/Impact-iPadK12-Schools.html

Shepherd, I. J., \& Reeves, B. (2011). iPad or $i F a d$ - The reality of a paperless classroom. Retrieved from http://www. acu.edu/technology/mobilelearning/ documents/research/ipad-or-ifad.pdf

Shuler, C. (2009). Pockets of potential: Using mobile technologies to promote children' s learning. New York: The Joan Ganz Cooney Center at Sesame Workshop.

Tate, C. (2012, March 27). Schools across the country bring iPads to the classroom, McClatchy Newspapers. Retrieved from http://www.mcclatchydc. com/2012/03/27/143268/schools-acrossthe-country-bring.html

Taylor, J. (2006). What are appropriate methods for evaluating learning in mobile environments? Evaluating mobile learning. In M. Sharples(Ed.), Big Issues in Mobile Learning. Nottingham, UK: Kaleidoscope Networks for Excellence, Mobile Learning Initiative.

Traxler, J. (2009). The evolution of mobile learning. In R. Guy (Ed.), The evolution of mobile teaching and learning (pp. 1-14). Santa Rosa, CA: Information Science Press. Wagoner, T., Hoover, S., \& Ernst, D. (2011). CEHD iPad initiative: Year one report. Retrived from http://www.cehd.umn.edu/ Mobile/PDF/CEHDiPadReport.pdf

Yin, R. K. (2003). Case study research: Design and methods (3rd ed.). Thousand Oaks: Sage. 


\section{Appendix 1: Teacher Focus Group Questions}

1. What are the factors that contribute or inhibit student learning with mobile devices?

2. What are the factors that contribute or inhibit teacher's facilitation of learning with mobile devices?

3. What can be improved in the next round of iPad implementation in terms of instructional strategies, institutional support, and teacher's professional development?

4. How did the iPad contribute to your teaching of Social Studies?

5. Anything else that we have not asked or considered and you would like to suggest?

\section{Appendix 2: Student Focus Group Questions}

1. What are the pros and cons of having iPad in the classroom?

2. In what ways, if any, has 1-to-1 learning with iPad in the classroom increased your creativity, innovation?

3. In what ways, if any, has 1-to-1 learning with iPad in the classroom decreased your creativity, innovation?

4. In what ways, if any, has 1-to-1 learning with iPad in the classroom increased your ability to communicate, collaborate, and solve problems?

5. In what ways, if any, has 1-to-1 learning with iPad in the classroom decreased your ability to communicate and collaborate, solve problems?

6. In what ways, if any, has 1-to-1 learning with iPad in the classroom increased your ability to conduct information search and practice digital citizenship (i.e., Internet safety, legal and ethical behavior)?

7. In what ways, if any, has 1-to-1 learning with iPad in the classroom decreased your ability to conduct information search and practice digital citizenship?

8. How can the process of iPad implementation be improved in the future?

9. What activities would you like to see in an iPad classroom?

10.How did the iPad impact your learning or understanding of topics related to Social Studies?

11. Did the use of iPad make a difference in your learning of the subject matters?

12. Is there anything you want to tell us about using iPad in the Social Studies classroom? 


\section{Appendix 3: Classroom Observation Form}

\begin{tabular}{|c|c|c|c|c|}
\hline Date: & \multicolumn{3}{|l|}{ Observer: } & \multirow[t]{4}{*}{ General Notes: } \\
\hline Teacher: & \multicolumn{3}{|l|}{ Class name: } & \\
\hline iPad for everyone? Yes / No & \multicolumn{3}{|c|}{$\#$ of students } & \\
\hline \multicolumn{2}{|l|}{ Phases of the class } & Start Time & End Time & \\
\hline \multirow{2}{*}{$\begin{array}{l}\text { Activity Description: } \\
\text { describe the activity } \\
\text { and interaction in the } \\
\text { classroom }\end{array}$} & $\begin{array}{l}\text { \# of } \\
\text { Students } \\
\text { in activity }\end{array}$ & Start Time & End Time & $\begin{array}{l}\text { Pros \& Cons } \\
\text { of iPads in the } \\
\text { classroom }\end{array}$ \\
\hline & & & & Pros: \\
\hline $\begin{array}{l}\text { ISTE NETS (check all that } \\
\square \text { Creativity \& innovation } \\
\square \text { Communication \& collab } \\
\square \text { Research \& information } \\
\square \text { Critical thinking, problen } \\
\square \text { Digital citizenship } \\
\square \text { Technology operations \& }\end{array}$ & $\begin{array}{l}\text { ration } \\
\text { solving \& de } \\
\text { concept }\end{array}$ & sion making & & Cons: \\
\hline
\end{tabular}

\section{Contact the Authors}

\section{Chientzu Candace Chou}

University of St. Thomas

Email: ccchou@stthomas.edu

\section{Lanise Block}

Minneapolis Public Schools

Email: Lanise.Block@mpls.k12.mn.us

\section{Renee Jesness}

Minneapolis Public Schools

Email: Renee.Jesness@mpls.k12.mn.us 